\title{
ウマの妊娠から出産までー生産率の向上は可能かー
}

\section{2. 種畜管理上の問題点}

日本軽種馬協会

中 西 信 吾

馬の受胎率が牛に比べ低いことは，これま た子馬を正常産駒として取り扱った。したが での報告から明らかであるが，その理由は， 主として馬の繁殖生理上の特異性にあるもの って，正常産駒を分娩した場合を生産とし， 妊娠と診断されたが生産しなかった場合（胎 子死滅, 流産, 死産, 産後直死など）を損耗 とした。

我国に扔ける近年の軽種馬の繁殖に関する デー夕は，毎年，日本軽種馬協会から刊行さ れる軽種馬生産統計に 1 年間の交配牝馬頭数 と子馬生産頭数が掲載されるに過ぎず，その ほかの詳細なデー夕は公表されていない。馬 の生産率の向上が可能か否かを検討するため には，馬の繁殖の現状を把握することが不可 欠である。

今回, 軽種馬の近年の繁殖状況を明らかに するために, 日本軽種馬協会の内部資料と同 協会軽種馬改良情報システムのデー夕を基に, 1984～1988年の軽種馬繁殖成績の分析を試み た。なお，繁殖牝馬の産歴に関しては，日本 軽種馬登録協会の血統書を用いて検索した。

調查対象は, 日本軽種馬協会所属の種牡馬 延べ151頭で交配した延べ4,009頭の繁殖牝馬 であった。その内訳は, サラブレッド延べ 3,741頭, アングロアラブ延べ246頭, アラブ 延べ20頭およびサラブレッド系延べ29頭であ った。各牝馬の繁殖成績から, 受胎率, 生産 率，および生産に関する損耗率を算出した。 なお, 本調查では, 分婏後 3 力月以上生存し

得られた結果の大要は, 以下に示すとおり である。

\section{1. 年次別繁殖成績}

1984～1988年の受胎率は74.1〜83.1\%でや やばらつきがみられた。生産率は受胎率と並 行しており，損耗率は $11 \%$ 前後のほぼ一定し た割合で推移していた。 5 年間の成績を通算 した繁殖成績は，受胎率が $79.3 \%$ ，生産率が $67.9 \%$ ，および損耗率が $11.4 \%$ あっった。

\section{2. 年齢別繁殖成績}

4 歳の受胎率は $76.1 \%$ で比較的低率であっ たが， 6 歳〜13歳までは10歳を除いて $80 \%$ を 超える良好な成績であった。14歳以上では受 胎率が漸減する傾向が明らかで, 20歳以上の

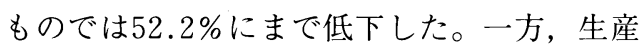
率は受胎率と並行して推移する傾向がみられ, 6 〜 13 歳が70\%前後の良好な値を示した。損 耗率は低年齢（4歳：17.4\%) のものと高齢 (18～19歳：16.3〜 17.9\%) のもので高い傾 向がみられ，その中間の年齢ではほぼ $11 \%$ 前 後であった。損耗率の大部分は，いずれの年

Reproductive management of mares during pregnancy - Possibility of raise in foaling rate - : 2. Problems on bloodhorse management.

Shingo NAKANISHI ; Japan Bloodhorse Breeders Association 
齢でも流産がその半数から $2 / 3$ 以上を占めて いた。

\section{3. 産次別繁殖成績}

0 産のものの受胎率はやや低かったが, 1 〜 2 産のものは $82.8 \%$ および $82.0 \%$ で最も高 かった。その後, 産次が増すにしたがって受 胎率は漸減する傾向が認められた。なお, 生 産率は年齢別にみた場合と同様に, 受胎率と 並行して変化した。損耗率は11産のもので高 率であったが, 年齢別にみたときのような明 確な傾向はみられなかった。

\section{4. 発情回次別繁殖成績}

調査した牝馬のうち 2 発情以上にわたって 交配を行ったのものは 1,773 頭であった。そ れぞれの交配発情回次の受胎率は, 第 1 ～ 回目は $49.2 \%, 48.4 \%$ および $45.4 \%$ で, 漸減 する傾向が認められた。しかし, 第 4 - 5 回 目では $31.6 \%, 20.9 \%$ と急隇し, 第 6 回と 7 回目の発情では受胎したものはなかった。ま た, 交配発情回次別の生産率は, 3 回目まで は40\%前後の值であったが，4回目は $26.6 \%$, 5 回目は $16.3 \%$ と著しく低率であった。しか し, 損耗率は交配発情回次が増すごとに良好 となる傾向があり，第 1 回目では $7.4 \%$ であ ったが第 5 回目までに $4.7 \%$ まで低下した。

\section{5. 授乳の有無による繁殖成績}

供試馬を授乳の有無, すなわち付牝馬と 子馬のいないものに区分すると, 前者は延べ 2,770 頭, 後者は 1,236 頭および不明が 3 頭で あった。

授乳馬の繁殖成績は受胎率 $81.0 \%$, 損耗率 $11.3 \%$ 拈よび生産率 $69.7 \%$ であったが, 非授 乳馬ではそれぞれ $75.7 \%, 11.7 \%$ 小よび 64.0\%であった。両者の損耗率にはあまり差 がみられないが, 授乳馬の方が受胎率では $5.3 \%$ 生産率では $5.7 \%$ 良好な成績が得られた。

\section{6. 前年度繁殖経歴別繁殖成績}

前年度の繁殖経歴を調査できた 1,514 頭を， 正常産駒を分婏した子付牝馬, 前年度に流産 や生後直死などの損耗が起こったもの（損耗 馬), 不受胎であったもの (不受胎馬), 初交 配のもの（初交配馬）および交配しなかった もの (未交配馬) の 5 つに分類し, 繁殖成績 を比較した。

最も受胎率が高かったのは子付牝馬の $79.0 \%$ で, 最も低率であったのは不受胎馬の $70.4 \%$ ，また，初交配馬は $72.5 \%$ と比較的低 率であった。損耗率が最も高かったのは初交 配馬の $13.8 \%$ であったが, 子付牝馬, 損耗馬 に比べそれほど高くなかった。なお，損耗率 が最も低かったのは不受胎馬の7.7\%であっ た。

\section{7 . 交配間隔}

2 発情以上にわたって交配を行った 1,773 頭の交配間隔は，18～24日が57.2\%と大多数 を占めていたが，それよりも遅れ25～87日間 隔で交配したものが $20.2 \%$ 認められた。この 原因について, 今回の調査では明かにできな かったが, 単に不受胎, 卵巣機能の障害だけ ではなく，早期肧死滅などによるものが多い と考えられるので, 今後の検討が必要である と思われる。

以上のことから本邦における軽種馬の繁殖 成績は世界的水準に達していることが知られ， また，損耗率 $11.4 \%$ のうち流産が $7.1 \%$ と大 部分を占めていることが明らかになった。し たがって，受胎率が現状のまま維持されると 仮定すれば，(1)流産発生時期を詳しく分析し， 予防可能なものについて適切な対策を講じ,

(2)周産期の管理技術を向上させ新生子馬の損 耗を減少させ，また(3)発情再帰日数の短縮す るもの, 延長するものの原因を究明し, 対策 
を講ずるならば, 軽種馬の生産率はある程度上を望むならば, 種畜の選抜にあたって乳牛 向上させることが可能だと考えられる。また，等の様に繁殖能力も考慮する必要があると思 軽種馬の種畜選抜は競走能力, 血統および体 われる。

型により行われているが, さらに受胎率の向

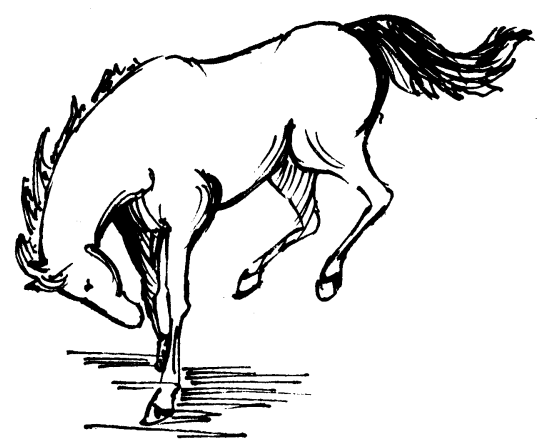

